\title{
Placenames of Scottish Origin in Nova Scotia
}

\section{Ian A. Fraser}

Of all the Canadian provinces, one would expect Nova Scotia to have a body of placenames of Scottish origin second to none outside the home country. The waves of immigration, from the latter part of the eighteenth century onwards, were mainly, though not entirely, Scots, many of them Gaelic speakers from the Highlands and Islands. The areas most favored by Scots settlers included the North Shore of Nova Scotia, especially Pictou and Antigonish Counties, and Cape Breton Island. By 1830, people of Scots origin comprised the largest ethnic group in the province. In the 1871 census, a third of the population of Nova Scotia was of Scots origin, with $78 \%$ of the population of Inverness County, in Cape Breton, and $86 \%$ of the population of Pictou County claiming Scots ancestry. 1

The custom of transferring placenames from the home country to the New World was practiced by the Scots in the same way as by any other immigrant ethnic group. Yet the Canadian colonies, Nova Scotia included, had been subjected to several influences whereby placenames had become established. The proportion of Scottish placenames, or placenames containing identifiably Scots elements, was lower in terms of the percentage of Scottish population.

The surveys carried out around the coasts of the Maritime Provinces had left a plethora of placenames, many of which reflected the work of government survey parties and the personal names of their staff, as well as those of the civil servants who administered the fast-developing new territories. The French Acadian population had a stock of placenames which were well established by the late eighteenth century, and Micmac Indian names - or at least corrupted forms of these - were in widespread use. There was, in addition, a deliberate policy of re-naming carried out by the British government after the fortress of Louisbourg was captured 
from the French in 1758. There seems to have been an attempt to replace existing French names in Cape Breton, and to a lesser extent on the mainland, with English placenames.

Samuel Holland, who was to become Surveyor-General of the northern division of North America, carried out a survey of Cape Breton Island in 1764. His "Description of Cape Breton Island" lists places which were clearly re-named after the French were ejected. The island of Boularderie, for example, at the outlet of the Bras d'Or Lake, is referred to as "Verderonne or St. George's Island" with the note "Monsieur Boulardrie the Proprietor in the French Time" (65). Tilbury Cove is referred to as "the remains of a French settlement ... called by the French St. Esprit, as also, the small island adjacent, but as the wreck of the Tilbury Man of War remains here, which was lost in the year 1757 , it is now named after her" (82). Both Boularderie and St. Esprit, however, are names which have survived, since French settlers trickled back to the province in the years after the fall of Louisbourg. It is clear from Holland's account, and from J.F.W. Des Barre's survey produced from 1776 to 1783 - a splendid set of coastal survey charts known as The Atlantic Neptune ${ }^{2}$ - that most of the Nova Scotian coast had been named in detail by 1780 . Settlers were not encouraged to apply for land in Cape Breton until 1784. The island had a separate government from then until $1820 .^{3}$ Scottish settlement reached its height in Nova Scotia in the years 1790 to $1830 .^{4}$

There were indeed few settlements in the province which were named by Scots settlers before 1800 , but after that date land grants to the many thousands of Scottish families who were trying to wrest a living from this largely inhospitable landscape resulted in a number of placenames of Scots origin. Some of these replaced existing topographic or descriptive names, while others - and there were many of these - used the names of the first Scottish settler to establish himself in the place. There is evidence that some Gaelic-speaking settlers used Gaelic forms of existing placenames in the initial stages of settlement. For example, Englishtown in Victoria County, which was a French fort prior to 1745, is on record as being called Bhal na Ghul by Gaelic speakers circa 1800 - presumably a corrupt Gaelic form of Baile nan Gall 'town of the foreigners.' However, Englishtown was the regular form from $1820 .^{5}$

The majority of placenames in Nova Scotia which have a Scottish connection were assigned in the nineteenth century. The earliest settlement in Antigonish County by Highlanders was as late as 1785 . This was called Arisaig, a placename directly transplanted from Inverness-shire in Scotland. But transference of this kind was exceptional. True, eastern Nova 
Scotia seems to have numbers of Scottish names, but on closer examination few are seen to have direct Scottish origins. In many cases, those Scots names involved have replaced previously existing non-Scots names. In a few recorded instances, Scottish names originally given were later changed. The severe depopulation which Nova Scotia experienced in the latter part of the nineteenth century, and the first few decades of the twentieth, was also a factor in name changes. The population of Antigonish County, for example, declined by $44 \%$ in the years $1881-1931 .^{6}$

Of the purely transferred names, Argyle occurs in both Yarmouth and Guysborough Counties. The normal form of this name in Scotland is now Argyll, but the spelling used in Nova Scotia reflects that in current use up to the middle of the last century. Beauly in Antigonish County appeared in 1871 , the place originally having been called Manchester Road. It is of particular interest, since the original Beauly in Inverness-shire, Scotland, is itself a transferred name, granted by Cistercian monks who founded a priory there in 1232. The name derives from the French beau lieu 'beautiful place.' Dunvegar' in Inverness County was so named in 1885 , as a replacement for the somewhat pedestrian Broad Cove Marsh. The name comes from the well-known seat of the Clan Macleod on the Isle of Skye. Gairloch Mountain and New Gairloch were named by settlers from Gairloch, Ross-shire, in the first decade of the nineteenth century, and Glencoe in Guysborough County became such by Act of Legislature in 1875, having originally been called "Back Settlement of Roman Valley." But there are places called Glencoe in Hants, Inverness, and Pictou Counties, some of which date from 1814. It was clearly a popular choice, with romantic Scottish links, as was Glengarry, a name which occurs in Pictou, Lunenburg, Inverness, and Cape Breton Counties. Glenroy in Antigonish was named after the valley in Lochaber, Scotland, about 1812, and Glenshee in Pictou County after the glen in Perthshire about 1820.

Granton in Pictou was reputedly named after the fishing village of the same name on the south shore of the River Forth near Edinburgh, and Inverness itself was called Broad Cove until 1903, when Sir William Young, its first representative in the Provincial Assembly, suggested Inverness as a suitable name for the then expanding town. Not surprisingly, Young was born in Inverness, Scotland. Iona in Victoria County had its name changed by statute from Grand Narrows in 1891, and Keppoch in Antigonish was settled by men from Keppoch in Lochaber in 1820. Knoydart, the name of a large and once-populous district in Inverness-shire, occurs in Pictou County. Many Gaels evicted from their lands in Knoydart settled in Nova Scotia. Laggan, Gaelic 'little hollow,' 
in Pictou originates in Inverness-shire also, with a founding date of c.1827. Lanark in Antigonish was part of a grant to an army officer called Hierlihy in 1784, and Loch Broom in Pictou was, according to traditional accounts, named after the parish in Ross-shire by one of its earliest settlers, Alexander Cameron, about 1775. Lochaber in Antigonish first appears in records about 1808. The district of Morar in Inverness-shire was one which suffered great depopulation and eviction in the nineteenth century, and many of its people settled in Antigonish County. The settlement of North Side Cape George changed its name to Morar in 1888. Ulva in Inverness County was named after the island in Argyll, Scotland. In addition, names like New Glasgow and New Edinburgh were obvious transferences from Scotland.

These names all have current parallels in the home country. Geographically, they reflect, for the most part, the places of origin of the original settlers. But many Nova Scotian placenames which ostensibly have been borrowed directly from Scotland are on closer examination found to have more complex origins. This is partly due to the fact that many Scottish personal names are derived from placenames in the home country. In this category is Dalhousie, which refers to a castle in Midlothian and the seat of the family of the same name. The Earl of Dalhousie was Governor of Nova Scotia in the early nineteenth century, and was instrumental in encouraging settlement in the province. It is not surprising that several settlements were named after him, in Annapolis, Kings, and Pictou Counties. Elgin in Pictou County was named after Lord Elgin, GovernorGeneral of British North America, 1847-1854. The name originates in an ancient town in Morayshire, Scotland. Another Governor-General of Canada, between 1878 and 1883, was the Marquis of Lorne, and Lorne in Pictou, Lornevale in Colchester, and Lorneville in Cumberland are named after him. Lorne is a district in Argyll in Scotland. Lennox, part of Stirlingshire, is found in Richmond County, and was named after Charles Lennox, 4th Duke of Richmond and Lennox. Melford in Guysborough County was named after the family seat of Sir Colin Campbell, Lieutenant-Governor of Nova Scotia 1834-40. Clearly the fashions in naming in the nineteenth century honored the senior administrators of the time. Many of these, of course, were members of the Scottish aristocracy, who were prominent in the colonial governments and seemed to welcome difficult and often challenging posts in the remoter outposts of the Empire. Some, like Dalhousie, were profound influences in the development and improvement of new settlements. ${ }^{7}$ 
It is probably true to say that this category of names has acquired primarily Canadian status because of these colonial administrators, and that the Scottish link is secondary. In the latter part of the twentieth century, most Canadians reasonably well-versed in their history will associate the names with the men involved, and not necessarily identify the placenames as Scottish at all. Yet, apart from derivative examples like Lornevale, all of them are current in Scotland.

The Gaelic element in Nova Scotian names is limited, and confined to a few names of relatively minor importance. When we consider the large number of Gaelic-speaking Scots who established themselves in the years 1780-1830 in counties like Inverness, Victoria, Pictou, and Antigonish, this is perhaps surprising. Few Gaelic names appear to have been new coinages, for, as we have seen, names transferred from Scotland were more widely acceptable, especially if the numerous non-Gaelic speakers found them easy to pronounce. It was obviously difficult for many genuine Gaelic settlement names to gain currency in the early years of the immigrations. However, examples like Ben Eoin 'Jonathan's Mountain' in Cape Breton County appeared in $\mathbf{1 8 3 9}$ as Baineoin. Loch Ban in Inverness County simply means 'white lake,' and although there are several parallels in Scotland, none is of sufficient importance to suggest that this is anything other than a name coined in Cape Breton by Gaelic-speaking settlers. The only other settlement names of any importance in this category are Skir Dhu at the mouth of the French River in Victoria County, a name which is an anglicized form of sgeir dhubh 'black searock or skerry,' and Kerrowgare, Pictou County, derived from the Gaelic ceathramh gearr 'short quarterland.' This latter name first appears on record in 1803.

Besides these names which have parallels in Scotland, or which themselves originated in Nova Scotia, we find fairly large numbers of settlement names which have a Scottish connection of some kind. These are (a) placenames involving personal names of Scottish origin, or (b) names containing toponyms which we can identify as being Gaelic or Scots. A good number of these must have had no direct Scottish link, being either Scots-Irish or imported from other parts of North America, especially with the influx of ex-soldiers who found life in British Nova Scotia preferable to remaining in an independent United States.

Among the first group, Highland personal names which were borne by early settlers form an important body. Gillis Brook in Antigonish, Gillis Cove in Inverness, and Gillis Lake in Cape Breton County testify to the large number of immigrants called Gillis or Gillies. Gillis Lake was 
named after a Donald Gillis, who was granted land there in 1838; it was originally called Elbegolkik in Micmac. Fraser Mountain in Pictou and Fraser's Grant in Antigonish, Glen Morrison in Cape Breton County, Kenzieville in Pictou (after William Mackenzie, a settler in 1807), McDonald Glen in Inverness, McIntyre Lake in Richmond, McKinnon's Harbour in Victoria, McPherson in Antigonish, and Matheson in Victoria are typical. All of these are well-established Highland surnames, and there are scores of them all over eastern Nova Scotia. Some have become anglicized or popularized, as in Kenzieville, Rankinville in Inverness County, and McLeanville in Cape Breton County. The element -ville does not occur in Scotland, and is clearly a response to the custom of nineteenth century settlers throughout North America which involved simply adding a vaguely fashionable habitative element to a surname or an occupational name. Wolfville, Waterville, and Kemptville are good examples of these in Nova Scotia. On occasion, a nickname finds its way onto the map, like Glen Tosh in Victoria County, the name of a place which was known as Big Hill in 1834. This was named in honor of the Rev. Abraham McIntosh, who was Presbyterian minister there in 1859-89.

Those Scottish toponymic elements which enter the picture here are few. Glen, the Scots borrowing from the Gaelic gleann 'valley,' is by far the most common, and has been used largely in its Scots form. Glen Bard in Antigonish commemorates the well-known Gaelic poet John Maclean, a native of the Isle of Tiree who settled in the area in 1819. Glen Campbell, Inverness, and Glen Currie, Cape Breton County, bear the surnames of early Scots settlers. Glendyer, Inverness, commemorates a man who erected a dyeing mill here in the middle of the nineteenth century. Glen Margaret in Halifax County was named about 1876 after Margaret, wife of James Fraser, a local resident. Glenholme in Colchester County, Glenkeen in Guysborough County, and Glenora in Inverness County are all names coined locally. The word burn, Scots 'stream' or 'brook,' occurs in several names, including Roseburn in Inverness County, which first appeared in 1887 replacing Bridge End, and Scotsburn in Pictou. Thorburn in Pictou, a mining settlement which was established in 1872, has a name which is very much manufactured, since it was originally called Vale Colliery. The new name, applied in 1886, derives apparently from that of the old Scandinavian God of Thunder, Thor.

With English being the language of advancement, it is not surprising that in those areas settled by Gaelic speakers Gaelic placenames suffered change and hybridization. Loch Lomond, a sizeable lake in Richmond County, Cape Breton, has a name transferred from Scotland. On its west 
shore is a settlement called Lockside, which must originally have been Lochside. This change is clearly due to the fact that non-Gaelic speakers found $c h[X]$ difficult to pronounce, and the resultant name is an anglicization. ${ }^{8}$ However, the place is spelt Lochside on the current 1:5,000,000 survey map of Nova Scotia, having been officially in this form since 1976 . Morvan in Antigonish is probably a form of Morvern, a parish in Argyll, Scotland.

A number of Nova Scotian placenames, naturally enough, refer to Scots as a distinct ethnic group. Highland Village in Colchester County was originally Scotch Village. Alba in Inverness County, a settlement founded in 1828 by Hebrideans, was known as Boom until 1893, when the name was changed. Alba is the Gaelic for Scotland, and indeed once referred to the whole of North Britain. Its re-appearance in the latter part of the twentieth century is evidence of the trend towards names with a Scottish flavor. Scotchtown in Cape Breton, Scotsville in Inverness County, and Scotch Village in Hants County all suggest populations which were originally of Scots origin.

The nineteenth century, especially the last quarter of it, was a period when there was considerable change in Nova Scotia placenames. There was a trend away from the descriptive placenames associated with the land-grants acquired by the early settlers. Some of these new forms may have been imposed by the Post Office Department, but there must have been a feeling in the community that prosperity and improved social and economic conditions made it necessary for some of the cumbersome old labels to be replaced by something a bit more imposing. Middle South River in Antigonish, for example, had its name changed to Dunmore; Yankee Grant in Antigonish was re-named Clydesdale in 1876; Young's Cover became Dingwall in 1883 at the suggestion of the local storekeeper, a man called Robert Dingwall. This is a Scottish surname, derived from the county town of Ross-shire in Scotland. Forks of Middle River officially became Glengarry in Pictou County in 1865; Grand Narrows Rear in Victoria County became St. Columbia. Some scattered settlements adopted names which then came to be applied to an enlarged area. Sunny Brae in Pictou combined Pleasant Valley, Fraser's Mills, and Upper Settlement in 1879.

Although the contribution made by Scots to the development of Nova Scotia has been immense, there are several revealing points to be made when we examine the placenames which are associated with them. Despite the fact that Victoria, Inverness, Cape Breton, Antigonish, and Pictou Counties were settled by large numbers of Gaelic-speaking 
immigrants, Gaelic has not been a prominent feature in the placenames of any of these counties. The majority of Gaelic speakers involved in the immigrations were illiterate in their own language, since Gaelic was, and to a certain extent still is, a tongue which very much depends on oral tradition for the maintenance of its culture, and which in the early part of the last century had little exercise in the way of written literature. Gaelic placenames were therefore little used, and such names as are associated with settlements of Gaelic speakers tend to be direct borrowings of existing Scottish names.

The period of expansion and consolidation of settlement in Nova Scotia (1830-1880) was characterized by a gradual assimilation of Gaelicspeaking immigrants into a much wider society. Gaelic declined, until by 1961 only $6.4 \%$ of the population of Inverness County could claim Gaelic as their mother tongue. The figure for the whole province was only $0.05 \%$. Today, only a few hundred people are fluent speakers, and these are mostly of the older generation. In the twentieth century "the Scottish culture was rapidly changing into a hybrid that was perhaps partScottish, part-Nova Scotian and part-Canadian."10

The Scottish connection, as far as Nova Scotia is concerned, continues to be maintained. Traditional music and song, for example, remain an expression of a distinctively Scottish heritage, although modified by nearly two centuries of settlement. The placenames, however, reflect the way in which Scots settlers integrated into a Maritime culture, which was rapidly acquiring its own separate traditions, and these names have to be seen in the context of their own time.

\section{Notes}

${ }^{1}$ See D. Campbell and R. A. MacLean, Beyond the Atlantic Roar. A Study of the Nova Scotia Scots, Carleton Library No. 78 (Toronto: McClelland and Stewart, 1974).

${ }^{2}$ The South East Corner of Cape Breton Island. Surveyed under the Direction of the Rt. Hon. Lords Commissioners of Trade and Plantations by Samuel Holland, Esqr., Survr. Genl. of the Lands of the Northern District of N. America and his Assistants, Mr. Thos. Wright, Jno. Pringle, Wm. Brown, Thos. Hanson, etc. (Published by Command of Government by Jos. Fred. W. Des Barres, Esqr., Oct. 1, 1781). The scale of this MS map, in the Library of Dalhousie University is ' $3 / 4$ miles to 1 '', i.e. $1: 47,520$.

${ }^{3}$ See Peggie M. Hobson, "Population and Settlement in Nova Scotia" in the Scottish Geographical.Magazine, Vol. 70, No. 2, September, 1954. 
${ }^{4}$ See J. S. Martell, Immigration to and Emigration from Nova Scotia (Halifax: Public Archives of Nova Scotia, 1942).

${ }^{5} \mathrm{C}$. Bruce Fergusson, Place-Names and Places of Nova Scotia.

${ }^{\circ} \mathrm{Campbell}$ and MacLean, p. 112.

${ }^{7}$ See Marjory Whitelaw, The Dalhousie Journals, Vols. 1 (1978), 2 (1981), and 3 (1982) (Ottawa: Oberon Press).

${ }^{8}$ Fergusson.

${ }^{9} \mathrm{Campbell}$ and MacLean, pp. 173-81.

${ }^{10}$ Ibid., p. 107. 